\title{
Pregnancy development from day 28 to 42 of gestation in postpartum Holstein cows that were either milked (lactating) or not milked (not lactating) after calving
}

\author{
Jacob C Green, Joseph P Meyer, Amanda M Williams, Emily M Newsom, Duane H Keisler and \\ Matthew C Lucy
}

Division of Animal Sciences, 158 Animal Science Research Center, University of Missouri, Columbia, Missouri 65211, USA

Correspondence should be addressed to M C Lucy; Email: lucym@missouri.edu

\begin{abstract}
The objective was to determine if lactation affects fetal and placental development from day 28 to 42 of gestation. Bos taurus Holstein cows were assigned to one of the two treatments immediately after parturition (lactating $(n=23)$ or nonlactating (dried off immediately after calving; $n=20)$ ). Cows were inseminated at $\sim 60$ days postpartum with semen from a single ejaculate. Pregnant cows were slaughtered at 1 of 3 days of gestation (day 28, 35, or 42) and tissues were collected. The interval to first insemination, services per conception, and days to pregnancy were similar for lactating and nonlactating cows. Lactating cows had greater plasma GH and nonesterified fatty acids. Nonlactating cows had greater plasma glucose, insulin, and IGF1. There was no effect of lactation on plasma progesterone or estradiol concentrations. Lactation had a negative effect on the weight of the fetus and placenta (weights were less in lactating cows). Fetuses collected from cows that became pregnant after first insemination were heavier than fetuses collected from cows that became pregnant after second or third insemination. Pregnancy after first insemination was associated with greater blood glucose and IGF1 during the first 30 days postpartum. The conclusions were that lactation negatively affects the growth of fetal and placental tissues perhaps through a mechanism that involves hormones and metabolites that are affected by lactation. Fetal growth within cows conceiving at first insemination compared to second or third insemination was more rapid and was associated with greater blood glucose and IGF1 early postpartum (before day 30 ).

Reproduction (2012) 143 699-711
\end{abstract}

\section{Introduction}

Physiological changes that support greater milk production may underlie the progressive decline in fertility experienced by dairy cows over the last half-century (Lucy 2003, Walsh et al. 2011). For example, lipid mobilization and nutrient partitioning in early lactation support greater lactation yield but also lead to lower body condition during the breeding period (Bauman \& Currie 1980). In cattle, low body condition portends poor reproductive performance (Roche et al. 2009). Specific changes in hormone and metabolites that may be either decreased (e.g. glucose, insulin, and IGF1) or increased (e.g. nonesterified fatty acids (NEFA) and ketone bodies) during nutrient mobilization may provide the physiological link between weight loss, lower body condition, and poor reproductive performance postpartum (Leroy et al. 2008a, 2008b). Ovarian gametogenesis and steroidogenesis are changed during lactation and the observed changes (for example, absence of ovulation or the ovulation of poor-quality gametes) affect fertility (Walsh et al. 2011). For those cows that ovulate a normal oocyte, suboptimal oviductal and uterine environment may provide a second barrier to the establishment of pregnancy (Walsh et al. 2011). The high metabolic rate associated with lactation impinges on the system as well. Steroids that are essential for the reproductive process may be more fully metabolized under conditions of high milk production and high dry matter intake (Wiltbank et al. 2006). Blood flow to the mammary gland increases postpartum so that nutrients such as glucose and NEFA that are used for milk synthesis are efficiently extracted from the circulation (Svennersten-Sjaunja \& Olsson 2005). In some case these same nutrients that are depleted in blood during lactation are also required for normal function of reproductive tissues within the nonpregnant animal (Sutton-McDowall et al. 2010). During pregnancy, for example, glucose is required by the embryo/fetus and placenta for metabolic energy and the creation of biomass (Bell \& Bauman 1997, Cetin \& Alvino 2009, Purcell \& Moley 2009). 
Pregnancy loss occurs when a viable embryo dies before pregnancy term. The majority of pregnancy loss in dairy cows occurs during the first 2 months of pregnancy (Santos et al. 2004, Diskin \& Morris 2008). There is an initial period of pregnancy loss between day 14 and 20 after fertilization when the elongating embryo is secreting interferon-tau for maternal recognition of pregnancy (Thatcher et al. 1995, Berg et al. 2010). A second major period of pregnancy loss occurs after this (up until day 60 of gestation). This latter period of pregnancy loss is perhaps more costly because the dam has invested more time in the pregnancy (Santos et al. 2004, Diskin \& Morris 2008). Embryonic loss during this period appears to be more common in high milk-producing postpartum dairy cows than in lower milk-producing cows or nonlactating heifers (Santos et al. 2004, Diskin \& Morris 2008). Although pregnancy loss in postpartum cows has been characterized and possible causal mechanisms have been proposed, few investigators have actually tested the effect of lactation itself on pregnancy development during this time.

We designed a study to investigate the direct effect of lactation on hormone and metabolic profiles as well as pregnancy development for cows that were first inseminated at $\sim 60$ days postpartum. Primiparous Holstein cows that calved were either milked twice daily (lactating group) or were dried off immediately after calving (nonlactating group). By using a contemporary group of cows that were not milked, we controlled for postpartum interval (identical for lactating and nonlactating) and eliminated possible confounding effects that arise when heifers (virgin reproductive tract; Sartori et al. 2004) or alternative sources of nonlactating cows (typically having long postpartum intervals; De la Sota et al. 1993) are used for comparison with early lactation cows. We retrospectively stratified the cows into whether they conceived or did not conceive at first insemination. Plasma hormone and metabolites were analyzed postpartum. Once pregnant, cows were slaughtered at 28, 35, or 42 days of pregnancy to assess the effect of lactation on the weight of the fetus, placenta, and corpus luteum $(\mathrm{CL})$.

\section{Results}

\section{$B W$, body condition, and milk production}

There was an effect of treatment by week for BW $(P<0.001)$. Lactating and nonlactating cows were similar for BW at week 1 postpartum $(582 \pm 13$ and $576 \pm 13 \mathrm{~kg}$ respectively). During the subsequent 3 week, lactating cows lost BW $(549 \pm 11 \mathrm{~kg}$ at week 4) whereas nonlactating cows maintained BW ( $573 \pm 11 \mathrm{~kg}$ at week 4$)$. Cows in both treatments gained BW afterward but the gain in BW was less for lactating $(570 \pm 12 \mathrm{~kg}$ at 12 week) compared to nonlactating $(645 \pm 12 \mathrm{~kg}$ at 12 week) cows.
There was an effect of treatment by week for body condition score (BCS; $P<0.001$; Fig. 1A). Lactating cows had a decrease in BCS from week $1(2.9 \pm 0.1)$ to week 4 $(2.6 \pm 0.1)$ and subsequently remained unchanged $(2.7 \pm 0.1$ at week 12$)$. Nonlactating cows were similar for BCS from week $1(3.1 \pm 0.1)$ to week $4(3.1 \pm 0.1)$ but then increased in BCS (3.8 \pm 0.1 at week 12). There appeared to be greater BCS loss in lactating cows that did not conceive at first insemination (Fig. 1A). The treatment by status by week interaction was not significant in the full model $(P=0.68)$ but the status by week interaction was significant $(P<0.02)$ in an analysis that included lactating cows alone. There was a status by week interaction for milk production in lactating cows $(P<0.001$; Fig. 1B). Cows that did not become pregnant at first insemination produced less milk during the first 6 week postpartum. Milk production was equivalent thereafter and averaged $31 \pm 1 \mathrm{~kg} /$ day for all cows at 12 week postpartum.
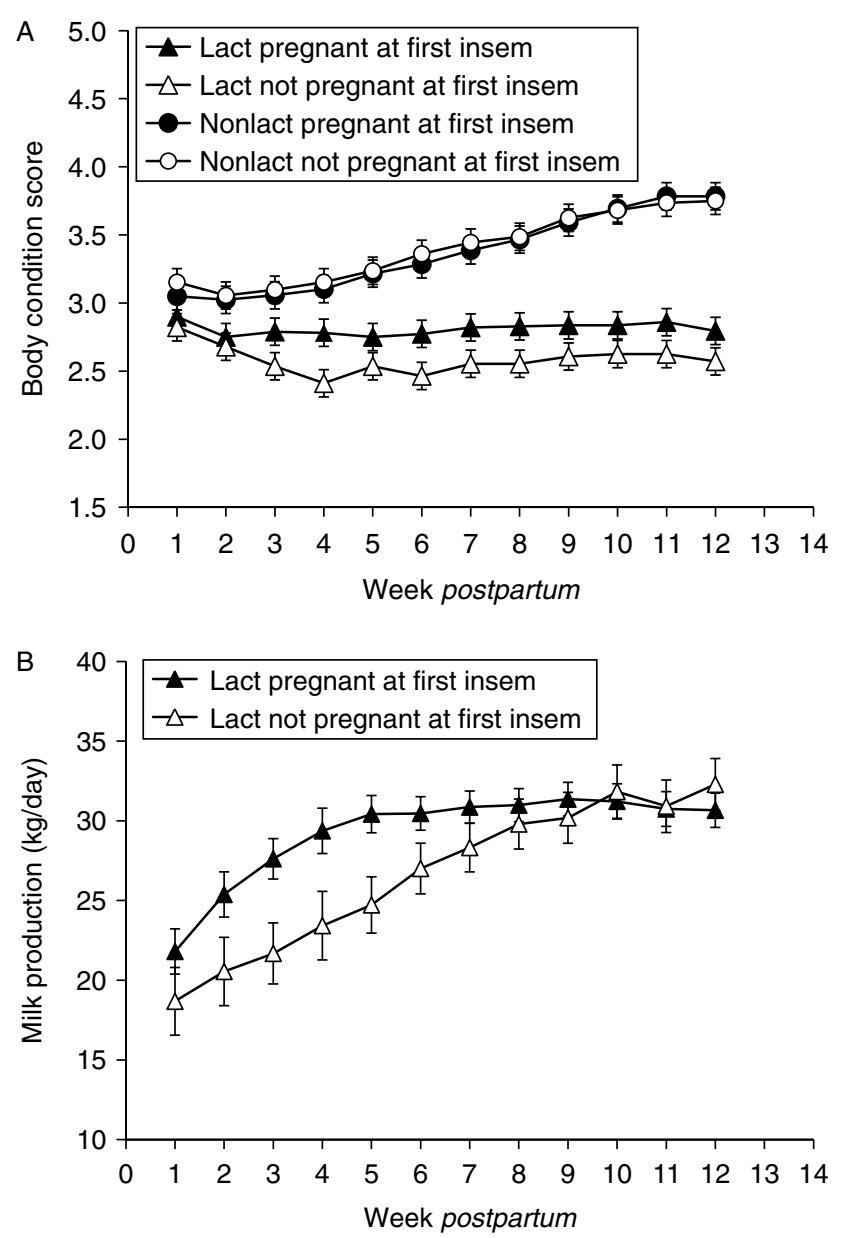

Figure 1 Least squares means and S.E.M. (bar) for BCS (A: 5-point scoring system; 1 (thin) to 5 (obese)) and milk production; (B: lactating cows only) for Bos taurus primiparous Holstein cows that were either lactating (Lact) or nonlactating (Nonlact; dried off immediately after calving) and were either pregnant or not pregnant to first insemination. 


\section{General reproductive characteristics}

The interval from calving to first ovulation (based on a sustained increase in plasma progesterone) was $\sim 10$ days lesser in nonlactating compared to lactating cows (Table 1). The percentage of lactating cows that had not ovulated by the time of the first GnRH was 13 and $43 \%$ for cows that were pregnant or not pregnant after first insemination. All of the nonlactating cows had ovulated by the time of the first GnRH injection of the synchronization program. Days to first insemination (60 \pm 1 days), first insemination conception rate (63\%), second insemination conception rate $(53 \%)$, services per conception $(1.5 \pm 0.1)$, and days from calving to conception $(74 \pm 4)$ were similar $(P>0.10)$ for lactating and nonlactating cows. The overall pregnancy rate before slaughter was $98 \%$ (42 of 43 cows) but two cows did not have a viable pregnancy (dead embryo found) at the time of slaughter (lactating, $n=1$; nonlactating, $n=1 ; 40$ out of 43 cows were truly pregnant, 93\%). The one cow that never became pregnant was nonlactating. The maximum number of inseminations for any cow was three.

\section{Plasma NEFA, glucose, GH, IGF1, and insulin concentrations}

Data presented in this section are for day 0-60 postpartum unless stated otherwise. Plasma NEFA concentrations were affected by treatment $(P<0.001)$, day $(P<0.001)$, and treatment by day $(P<0.001$; Fig. 2A). Lactating cows had greater plasma NEFA concentrations than nonlactating cows $(436 \pm 31$ vs

Table 1 Least square means \pm S.E.M. for measures of postpartum reproduction and fertility for primiparous Bos taurus Holstein cows that were either lactating or nonlactating (dried off immediately after calving).

\begin{tabular}{|c|c|c|c|}
\hline \multirow[b]{2}{*}{ Item } & \multicolumn{2}{|c|}{ Treatment } & \multirow[b]{2}{*}{$\boldsymbol{P}<<^{\mathrm{a}}$} \\
\hline & Lactating & Nonlactating & \\
\hline$n$ & 23 & 20 & \\
\hline Days to first ovulation (day) ${ }^{b}$ & $28.2 \pm 2.8$ & $18.3 \pm 2.8$ & 0.018 \\
\hline Days to first insemination (day) & $60.2 \pm 0.8$ & $60.8 \pm 0.9$ & NS \\
\hline $\begin{array}{l}\text { First insemination conception } \\
\quad \text { rate }(\%)^{\mathrm{c}}\end{array}$ & $69.6(\overline{16} / 23)$ & $55.0(\overline{11} / 20)$ & NS \\
\hline $\begin{array}{l}\text { Second insemination } \\
\text { conception rate }(\%)^{\mathrm{c}}\end{array}$ & $66.7(4 / 6)$ & $44.4(4 / 9)$ & NS \\
\hline Inseminations per conception & $1.36 \pm 0.17$ & $1.68 \pm 0.18$ & NS \\
\hline Calving to conception (day) & $69.2 \pm 5.0$ & $79.6 \pm 5.4$ & NS \\
\hline Pregnancy rate $(\%)^{\mathrm{d}}$ & 100 & $9 \overline{5}$ & NS \\
\hline $\begin{array}{l}\text { Number of corpora lutea at } \\
\text { slaughter }\end{array}$ & $1.2 \pm 0.1$ & $1.2 \pm 0.1$ & NS \\
\hline Cows with twin pregnancies (\%) & 8.7 & 15.8 & NS \\
\hline
\end{tabular}

${ }^{a} P$ value for the effect of treatment; NS, not significant, $P>0.10$.

${ }^{b}$ Defined as the sample day before the first sustained increase plasma progesterone above $0.5 \mathrm{ng} / \mathrm{ml}$. ${ }^{C}$ Hundred times the number of pregnant cows divided by the number of inseminated cows. ${ }^{\mathrm{d}}$ Hundred times the number of pregnant cows divided by the total number of lactating or nonlactating cows.
$189 \pm 30 \mu \mathrm{Eq} / \mathrm{l}$ respectively). Plasma NEFA declined over time in both treatments so that NEFA for lactating and nonlactating cows converged toward the end of the sampling period (after day 40). The effects of status (pregnant after first insemination or not pregnant after first insemination), status by treatment, status by day, and status by treatment by day were not significant $(P>0.10)$.

There was an effect of treatment on plasma glucose $(P<0.001$; Fig. 2B). Lactating cows had lesser plasma glucose concentrations compared with nonlactating cows $(65.7 \pm 0.9$ vs $77.4 \pm 0.9 \mathrm{mg} / \mathrm{dl}$ for lactating and nonlactating cows). There was also a status by day postpartum interaction for plasma glucose $(P<0.01)$. On several days, particularly during the first month after calving, plasma glucose concentrations were greater in those cows that subsequently became pregnant at first insemination compared with those cows that were not pregnant after first insemination. When data were analyzed as two separate periods (day 0-30 or day 31-60), plasma glucose concentrations were greater for first insemination pregnant (status $=1$ ) than first insemination not pregnant cows $($ status $=0$ ) during period 1 (day $0-30 ; 72.9 \pm 0.9$ vs $68.8 \pm 1.2 \mathrm{mg} / \mathrm{dl}$ for statuses 1 and 0 respectively; $P<0.01$ ), but were similar for statuses 1 and 0 during period 2 (day $31-60 ; 72.4 \pm 0.8$ and $72.0 \pm 1.1 \mathrm{mg} / \mathrm{dl}$ for statuses 1 and 0 respectively; $P>0.10$ ).

There was an effect of treatment $(P<0.01)$, days postpartum $(P<0.001)$, and treatment by days postpartum $(P<0.01)$ on plasma $\mathrm{GH}$ concentrations. Lactating cows had greater plasma $\mathrm{GH}$ concentrations than nonlactating cows $(P<0.002 ; 14.9 \pm 1.7$ and $6.8 \pm 1.7 \mathrm{ng} / \mathrm{ml}$ for lactating and nonlactating cows respectively; Fig. 2C). In both lactating and nonlactating cows, GH concentrations decreased with increasing days $(12.9 \pm 2.2 \mathrm{ng} / \mathrm{ml}$ on day $0-6.7 \pm 2.8 \mathrm{ng} / \mathrm{ml}$ on day 60). Plasma GH concentrations for cows that became pregnant after first insemination (status $=1$ ) were similar to plasma $\mathrm{GH}$ concentrations for cows that were not pregnant after first insemination (status $=0$ ). The effects of status by treatment, status by day, and status by treatment by day were not significant $(P>0.10)$.

There was an effect of treatment $(P<0.001)$, days postpartum $(P<0.001)$, and treatment by days postpartum $(P<0.001)$ for plasma IGF1 (Fig. 2D). Lactating cows had lesser plasma IGF1 concentrations than did nonlactating cows $(115.0 \pm 6.9$ and $181.7 \pm 6.9 \mathrm{ng} / \mathrm{ml}$ for lactating and nonlactating cows respectively). Regardless of treatment, plasma IGF1 concentrations increased with increasing days postpartum but this increase was more-rapid in nonlactating cows. There was an effect of status $(P<0.017)$ on plasma IGF1 concentrations because, regardless of treatment, cows that became pregnant at first insemination (status $=1$ ) had greater IGF1 concentrations than cows that did not become pregnant after first insemination (status $=0$ ) (lactating cows, $125.2 \pm 7.7$ and $104.7 \pm 11.6 \mathrm{ng} / \mathrm{ml}$ for 

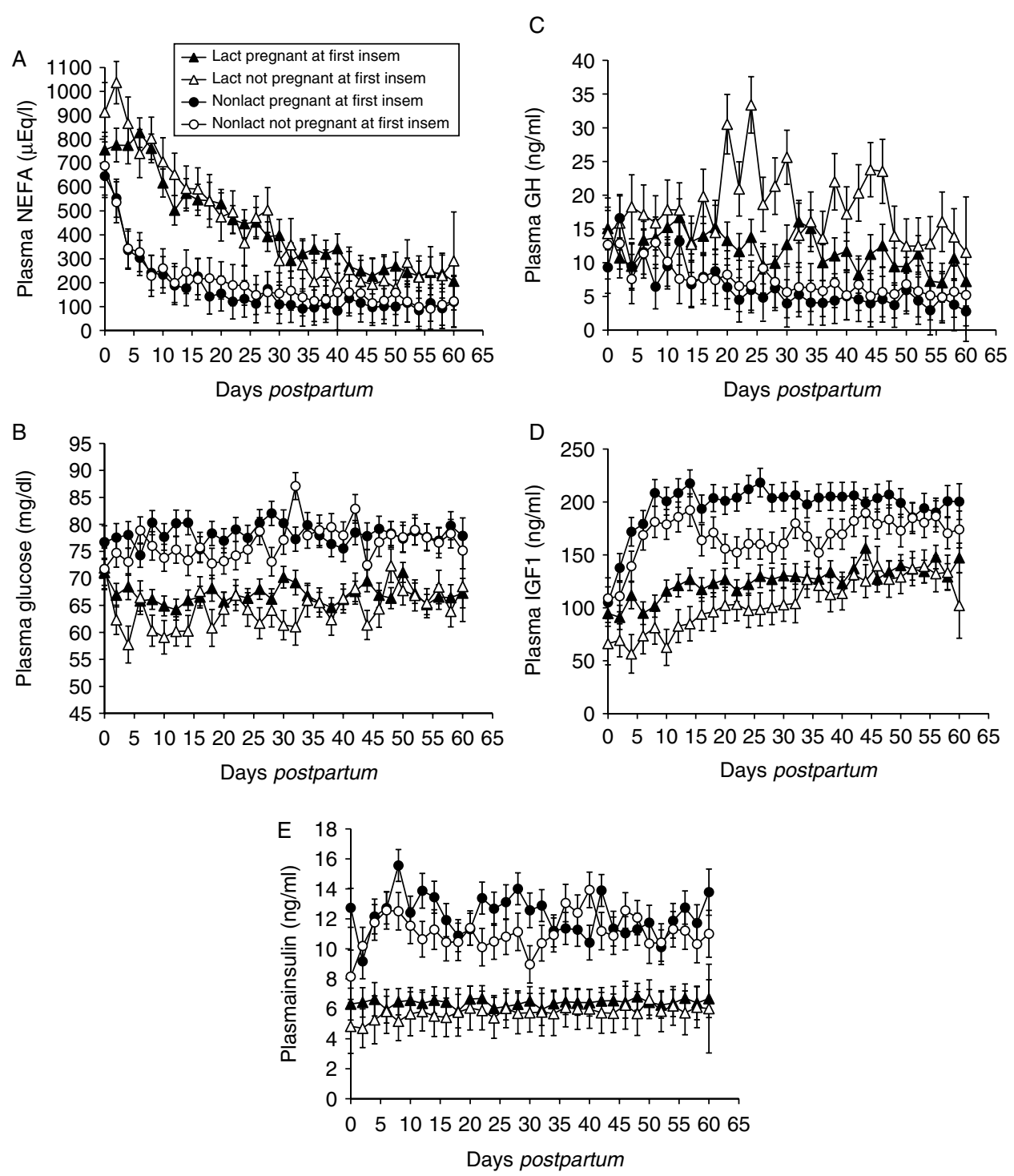

Figure 2 Least squares means and S.E.M. (bar) for plasma concentrations of (A) NEFA, (B) glucose, (C) GH, (D) IGF1, and (E) insulin during the first 60 days postpartum for Bos taurus primiparous Holstein cows that were either lactating (Lact) or nonlactating (Nonlact; dried off immediately after calving) and were either pregnant or not pregnant at first insemination. Symbols in panel A apply to all graphs.

statuses 1 and 0 cows respectively; nonlactating cows, $195.9 \pm 9.2$ and $167.4 \pm 10.2 \mathrm{ng} / \mathrm{ml}$ for statuses 1 and 0 cows respectively). Data were subsequently analyzed for plasma IGF1 concentrations during periods 1 and 2 (0-30 and 31-60 days postpartum respectively). Cows that became pregnant after first insemination (status $=1$ ) had greater plasma IGF1 concentrations during period 1 than cows that failed to become pregnant after first insemination (status 1, $152.8 \pm 7.0 \mathrm{ng} / \mathrm{ml}$ and status $0,121.6 \pm 9.1 \mathrm{ng} / \mathrm{ml} ; P<0.01)$. During period 2 (31-60 days postpartum), IGF1 concentrations only tended to differ for statuses 1 and 0 cows $(167.8 \pm 6.0$ and $149.8 \pm 7.7 \mathrm{ng} / \mathrm{ml}$ respectively; $P<0.08$ ).

There was an effect of lactation on plasma insulin $(P<0.001$; Fig. 2E). Lactating cows had lesser plasma insulin than nonlactating cows $(6.0 \pm 0.5$ and
$11.7 \pm 0.5 \mathrm{ng} / \mathrm{ml}$ for lactating and nonlactating cows respectively). Neither the interactions of main effects with treatment nor interactions of main effects with status were significant for plasma insulin $(P>0.10)$.

\section{Plasma progesterone and estradiol concentrations}

Eleven lactating cows and 18 nonlactating cows had a luteal phase (basal plasma progesterone followed by a sustained elevation in progesterone) after the first $\mathrm{PGF}_{2 \alpha}$ injection ( $\sim 25$ days postpartum; luteal phase 1; Fig. 3 ). The reasons for excluding cows from the analysis of luteal phase 1 were that they were either anovular (six lactating and two nonlactating), they failed to regress the $\mathrm{CL}$ after the $\mathrm{PGF}_{2 \alpha}$ injection (five lactating and 0 nonlactating; progesterone $>1 \mathrm{ng} / \mathrm{ml}$ at 2 days after 

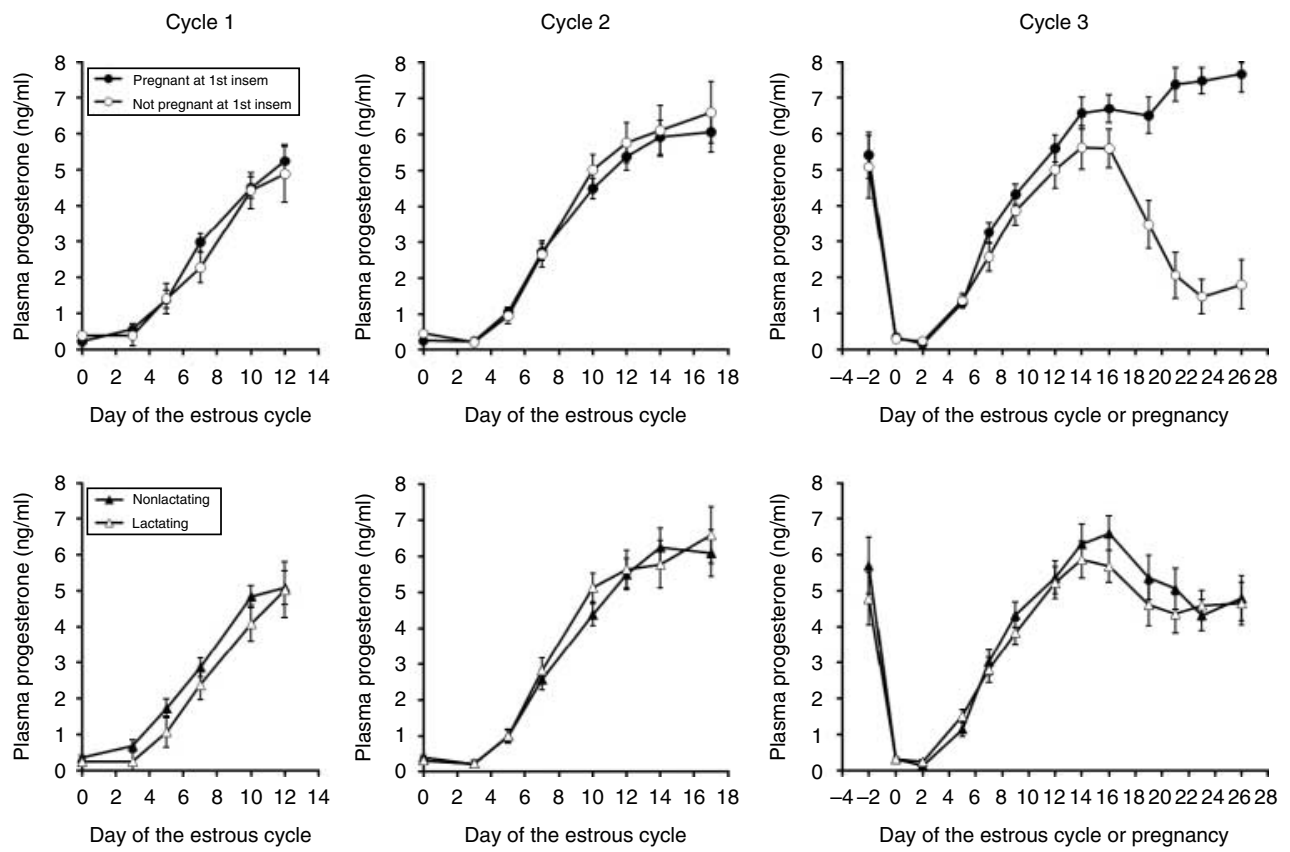

Figure 3 Least squares means and S.E.M. (bar) for plasma concentrations of progesterone for Bos taurus primiparous Holstein cows that were either lactating or nonlactating (dried off immediately after calving) and were either pregnant or not pregnant at first insemination. Means are for the main effects of treatment (lactating or nonlactating) and status (pregnant or not pregnant at first insemination) during cycle 1 (luteal phase after first PGF $2 \alpha$ injection), cycle 2 (luteal phase after second $\mathrm{PGF}_{2 \alpha}$ injection), and cycle 3 (luteal phase after third $\mathrm{PGF}_{2 \alpha}$ injection when cows were inseminated).

$\mathrm{PGF}_{2 \alpha}$ ) or they failed to ovulate after the $\mathrm{PGF}_{2 \alpha}$ injection (one lactating and 0 nonlactating; $<1 \mathrm{ng} / \mathrm{ml}$ at 14 days after $\mathrm{PGF}_{2 \alpha}$ ). As expected, there was an effect of day $(P<0.001)$ on plasma progesterone concentrations during luteal phase 1 . There was no effect of lactation, status, or their interactions on plasma progesterone during luteal phase 1.

Fifteen lactating cows and 15 nonlactating cows had a luteal phase after the second $\mathrm{PGF}_{2 \alpha}$ injection ( $\sim 39$ days postpartum; Fig. 3; luteal phase 2). The reasons for excluding cows from the analysis were that they were either anovular (five lactating and one nonlactating), they failed to regress the $\mathrm{CL}$ after the $\mathrm{PGF}_{2 \alpha}$ injection (three lactating and two nonlactating) or they failed to ovulate after the $\mathrm{PGF}_{2 \alpha}$ injection (0 lactating and two nonlactating). There was an effect of day $(P<0.001)$ on plasma progesterone concentrations during luteal phase 2 . There was no effect of lactation, status, or their interactions on plasma progesterone during luteal phase 2 .

Twenty-two lactating and 18 nonlactating cows had a luteal phase after the third $\mathrm{PGF}_{2 \alpha}$ injection (the $\mathrm{PGF}_{2 \alpha}$ that immediately preceded timed artificial insemination (Al); luteal phase 3$)$ ). The reasons for excluding cows from the analysis were that they were either anovular at $\mathrm{PGF}_{2 \alpha}$ (one nonlactating), they failed to ovulate after the $\mathrm{PGF}_{2 \alpha}$ injection (one nonlactating), or they were inseminated before the $\mathrm{PGF}_{2 \alpha}$ injection (one lactating). Plasma progesterone concentrations were similar for lactating and nonlactating cows before and after the third $\mathrm{PGF}_{2 \alpha}$ injection (Fig. 3). As expected, there were effects of status, day, and status by day $(P<0.001)$. Cows that did not conceive at first insemination (status $=0$ ) underwent luteal regression toward the end of the sampling period, whereas pregnant cows $($ status $=1$ ) had a sustained elevations in progesterone. If only data from the mid-luteal phase (day 7-16) were included, then there was a tendency for an effect of status $(P<0.10)$ because cows that became pregnant had greater plasma progesterone than cows that did not become pregnant $(5.3 \pm 0.3$ and $4.5 \pm 0.4 \mathrm{ng} / \mathrm{ml}$ respectively).

Plasma estradiol concentrations were greater $(P<0.001)$ at 0 and $48 \mathrm{~h}$ after the third injection of $\mathrm{PGF}_{2 \alpha}$ for cows that became pregnant at the time of first Al compared with those that did not become pregnant (Fig. 4A). There was also an effect of time because plasma estradiol increased from $4.0 \pm 0.4$ to $6.8 \pm 0.4 \mathrm{pg} / \mathrm{ml}$ from 0 to $48 \mathrm{~h}$ respectively. There was no effect of treatment on plasma estradiol after the third $\mathrm{PGF}_{2 \alpha}$ injection (Fig. 4B).

\section{Pregnancy-associated glycoproteins}

Plasma pregnancy-associated glycoprotein (PAG) concentrations were analyzed after insemination for cows that were known to be pregnant after first, second, or third insemination (Fig. 5). Three periods were analyzed separately (day 15-27; pregnant cows slaughtered on day 28, 35, or 42, all cows; day 29-34, pregnant cows slaughtered on day 35 or 42 ; and day 36-41, pregnant cows slaughtered on day 42). There was no 

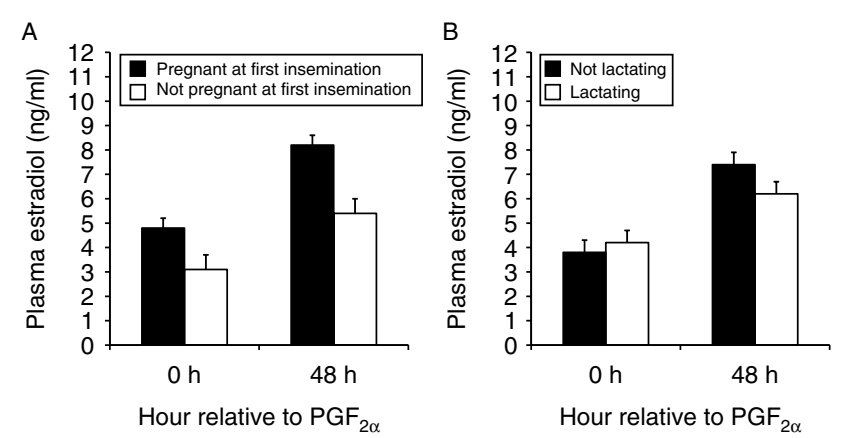

Figure 4 Least squares means and S.E.M. for plasma concentrations of estradiol at the time of the third $\mathrm{PGF}_{2 \alpha}$ injection $(0 \mathrm{~h} ; 3$ days before first insemination) and $48 \mathrm{~h}$ later for Bos taurus primiparous Holstein cows that were either (A) pregnant or not pregnant at first insemination, or were either (B) lactating or nonlactating (dried off immediately after calving). Means are for the main effects of status (pregnant or not pregnant at first insemination) and treatment (lactating or not lactating).

effect of treatment or treatment by day interaction for PAG concentrations during any of the intervals tested. There was an effect of status for plasma PAG on day $15-27(P<0.05)$ and day 29-34 $(P<0.09)$ because cows that were pregnant after first insemination had greater plasma PAG concentrations when compared with cows that were pregnant after second or third insemination. Status was not significant for PAG concentrations from day 36 to $41(P>0.10)$.

\section{Development of the $C L$, fetus, and placenta}

There was an effect of day on $\mathrm{CL}$ weight $(P<0.064$; Table 2) because the average weight of the $C L$ increased from day $28(6.2 \pm 0.6 \mathrm{~g})$ to day $42(8.4 \pm 0.6 \mathrm{~g})$. There was no effect of treatment or status on $\mathrm{CL}$ weight or the number of $C L$ on the ovary $(1.2 \pm 0.1$; Table 1$)$.

There was an effect of treatment $(P<0.05$; Table 2$)$, status $(P<0.01$; Table 3$)$, and day $(P<0.001)$ for fetal weight. The interactions of the main effects were not significant. The fetus grew larger from day 28 to 42, but that increase was greater in nonlactating compared with lactating cows (Table 2). There was also an effect of status because cows that conceived at first Al had fetuses of greater weight when compared with cows that conceived at second or third Al (Table 3). Fetal length was affected by day $(P<0.001)$ but not by the additional effects in the model. There was an effect of treatment $(P<0.01)$, day $(P<0.001)$, and a tendency for an effect of treatment by day $(P<0.056)$ on placental weight. After day 28 , the placenta was heavier in nonlactating cows compared with the lactating cows. The effect of status was not significant for placental weight. Placental fluid volume was affected by treatment $(P<0.024$; Table 2$)$, day $(P<0.001$; Table 2$)$, and status $(P<0.014$; Table 3$)$. The placental fluid volume increased, as expected, from day 28 to 42 and nonlactating cows had greater placental volume than lactating cows. Cows that conceived at first Al had greater placental volume than cows that conceived at second or third Al (effect of status; Table 3).

Twin pregnancies were found in two lactating and three nonlactating cows. Individual fetal weights for the twin pregnancies were: lactating day 28 pregnancy, 0.03 and $0.07 \mathrm{~g}$; lactating day 35 pregnancy, 0.14 and $0.67 \mathrm{~g}$; nonlactating day 35 pregnancy, 0.19 and $1.19 \mathrm{~g}$; nonlactating day 35 pregnancy, 0.81 and $1.72 \mathrm{~g}$; and nonlactating day 42 pregnancy, 1.51 and $1.87 \mathrm{~g}$.

\section{Discussion}

The study described herein is one of the first of its kind to specifically address the direct effects of lactation on pregnancy development between day 28 and 42 in dairy cows. The first major finding from this study was that lactation led to slower pregnancy development (smaller fetuses and placenta and less placental fluid at a given day of pregnancy). The development of a placenta is an obvious requirement for the establishment of pregnancy but whether or not slower pregnancy development predisposes a lactating cow to embryonic loss is a question that was not specifically addressed in this trial. Pregnancy loss declines greatly after 60 days of pregnancy perhaps because the placentomes are fully formed and tenuous contacts between the uterus and placenta no longer exist (Santos et al. 2004, Diskin \& Morris 2008). Before day 60, the trophoblast is loosely attached or is not attached to the uterus via the placentome (King et al. 1979, 1980). A slower developing fetus and placenta may be at risk because the fetal/placental unit spends more time in this loose attachment phase (after maternal recognition of pregnancy). This argument assumes, of course, that the smaller fetal/placental unit is at an earlier developmental

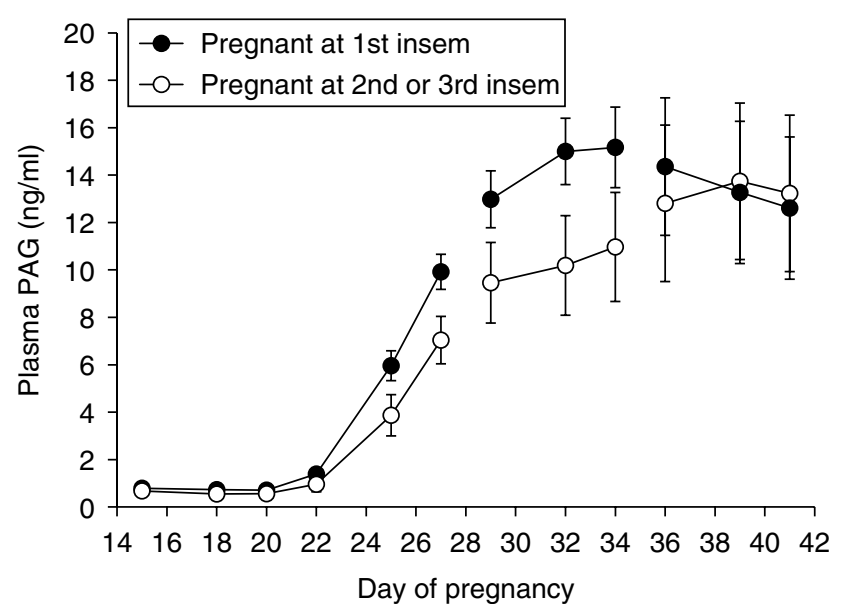

Figure 5 Least squares means and S.E.M. for plasma concentrations of PAG from day 15 to 42 of pregnancy for Bos taurus primiparous Holstein cows that were either lactating or nonlactating (dried off immediately after calving) and were either pregnant at first insemination or were pregnant at second or third insemination. 
Table 2 Least square means \pm S.E.M. for weight of the corpus luteum, and for fetal and placental measurements for primiparous Bos taurus Holstein cows that were either lactating or nonlactating (dried off immediately after calving) and had tissues collected on either day 28, 35, or 42 of pregnancy.

\begin{tabular}{|c|c|c|c|c|c|c|}
\hline \multirow[b]{2}{*}{ Item } & \multicolumn{3}{|c|}{ Day of pregnancy } & \multicolumn{3}{|c|}{$\boldsymbol{P}<^{\mathrm{a}}$} \\
\hline & 28 & 35 & 42 & Trt & Day & $T \times D$ \\
\hline CL wt (g) & & & & NS & 0.064 & NS \\
\hline Lactating & $6.0 \pm 1.0$ & $7.9 \pm 0.8$ & $8.6 \pm 0.8$ & & & \\
\hline Nonlactating & $6.5 \pm 0.8$ & $7.1 \pm 1.1$ & $8.1 \pm 0.9$ & & & \\
\hline Fetal weight (g) & & & & 0.049 & 0.001 & NS \\
\hline Lactating & $0.10 \pm 0.13$ & $0.61 \pm 0.10$ & $1.64 \pm 0.10$ & & & \\
\hline Nonlactating & $0.12 \pm 0.10$ & $0.79 \pm 0.13$ & $2.02 \pm 0.11$ & & & \\
\hline Fetal length (mm) & & & & NS & 0.001 & NS \\
\hline Lactating & $7.2 \pm 1.4$ & $14.7 \pm 1.1$ & $24.8 \pm 1.0$ & & & \\
\hline Nonlactating & $8.0 \pm 1.1$ & $16.7 \pm 1.4$ & $26.3 \pm 1.2$ & & & \\
\hline Placental weight (g) & & & & 0.005 & 0.001 & 0.056 \\
\hline Lactating & $1.1 \pm 1.9$ & $8.3 \pm 1.6$ & $16.8 \pm 1.4$ & & & \\
\hline Nonlactating & $1.2 \pm 1.6$ & $12.7 \pm 2.0$ & $25.0 \pm 1.5$ & & & \\
\hline Placental fluid (ml) & & & & 0.024 & 0.001 & NS \\
\hline Lactating & $8.1 \pm 11.6$ & $52.5 \pm 9.4$ & $121.8 \pm 8.6$ & & & \\
\hline Nonlactating & $11.1 \pm 9.1$ & $78.7 \pm 11.6$ & $152.7 \pm 9.7$ & & & \\
\hline
\end{tabular}

${ }^{a} P$ value for the effect of treatment (Trt), day of pregnancy (day), and the interaction of treatment and day of pregnancy $(T \times D)$. NS, not significant, $P>0.10$.

stage and not simply smaller and at the same developmental stage with equivalent placentome development. We did not perform a detailed developmental analysis of the fetus or placenta itself. Our general impression was that lighter fetal/placental units in lactating cows were less developed (earlier stage), but this will need to be confirmed in subsequent experiments.

We observed considerable plasticity in terms of pregnancy development in postpartum cows. We assumed that the development of the fetus and placenta would be largely similar for a given day of pregnancy. This was clearly not the case (an example of this is depicted in Fig. 6). Cattle at a similar day of pregnancy may have vastly different fetal and placental development. What constitutes a 'normal' range in development in the postpartum cow between day 28 and 42 is largely unknown because few slaughter studies have been completed. Whether or not these differences in terms of fetal and placental development have a consequence in terms of pregnancy loss are unknown. Presumably the slower developing pregnancy is at risk but this assumption will need to be tested. In addition to large variation in single pregnancies (between cattle), we also found that twin pregnancies found in the same cow could be comprised of two similar sized fetuses (e.g. 1.51 and $1.87 \mathrm{~g}$ at day 42 in Cow 6) or one large and one small fetus (e.g. 0.14 and $0.67 \mathrm{~g}$ at day 35 in Cow 10). Apparently two fetuses can develop at entirely different rates even when they reside within the same uterus. Again, the consequences of these differences in development are not known, i.e. does the smaller fetus eventually die or does it catch-up developmentally to the larger fetus at some later time?

The results of this trial were also remarkable in terms of the treatment differences that were not found. For example, regardless of treatment (lactating or nonlactating), there was very high fertility (conception rate) for the cows enrolled in this trial ( $>50 \%$ conception rate for inseminations that occurred at $\sim 60$ days postpartum).

Table 3 Least square means \pm s.E.M. for fetal and placental measurements for primiparous Bos taurus lactating and nonlactating Holstein cows that had tissues collected on either day 28, 35, or 42 of pregnancy and were pregnant from either the first or second/third insemination.

\begin{tabular}{|c|c|c|c|c|c|c|}
\hline \multirow[b]{2}{*}{ Item } & \multicolumn{3}{|c|}{ Day of slaughter } & \multicolumn{3}{|c|}{$\boldsymbol{P}<<^{\mathrm{a}}$} \\
\hline & 28 & 35 & 42 & Status & Day & $S \times D$ \\
\hline Fetal weight (g) & & & & 0.003 & 0.001 & NS \\
\hline First insemination & $0.14 \pm 0.10$ & $0.91 \pm 0.08$ & $2.05 \pm 0.10$ & & & \\
\hline Second or third insemination & $0.08 \pm 0.13$ & $0.49 \pm 0.16$ & $1.61 \pm 0.11$ & & & \\
\hline Placental weight (g) & & & & NS & 0.001 & NS \\
\hline First insemination & $1.49 \pm 1.40$ & $11.0 \pm 1.29$ & $21.5 \pm 1.39$ & & & \\
\hline Second or third insemination & $0.73 \pm 2.10$ & $10.0 \pm 2.28$ & $20.2 \pm 1.57$ & & & \\
\hline Placental fluid (ml) & & & & 0.014 & 0.001 & NS \\
\hline First insemination & $14.1 \pm 8.6$ & $75.9 \pm 7.2$ & $155.2 \pm 8.6$ & & & \\
\hline Second or third insemination & $5.1 \pm 12.1$ & $55.3 \pm 14.1$ & $119.3 \pm 9.7$ & & & \\
\hline
\end{tabular}

${ }^{\mathrm{a}} P$ value for the effect of status, day of pregnancy (day), and the interaction of status and day of pregnancy $(S \times D)$. NS, not significant, $P>0.10$. 

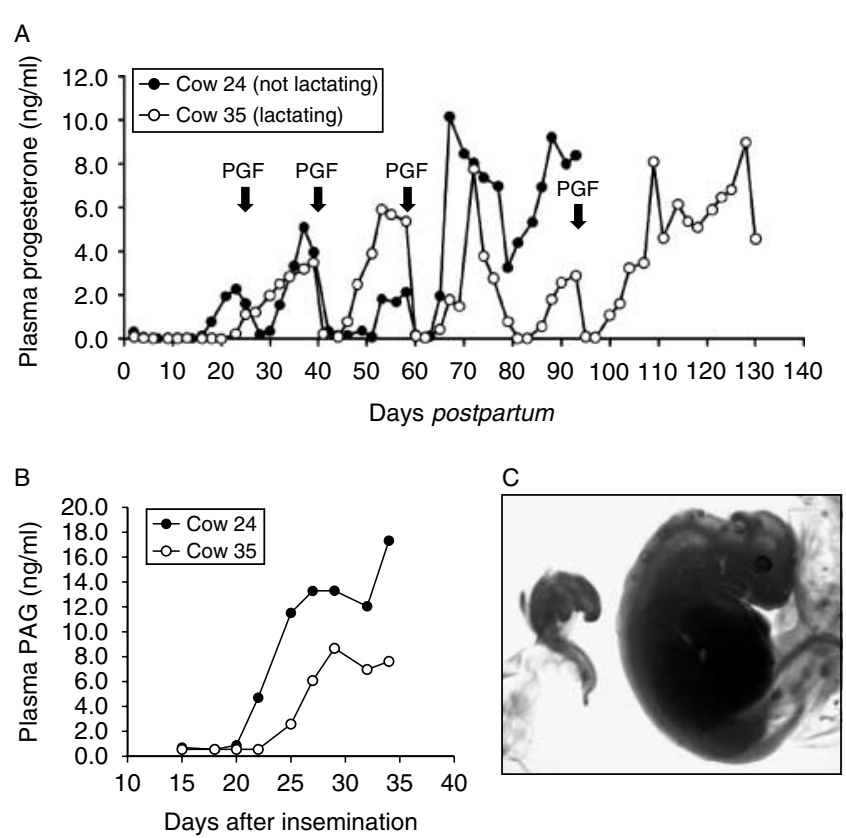

Figure 6 Postpartum (A) plasma progesterone and (B) PAG for two Bos taurus primiparous Holstein cows whose fetuses $(C)$ were collected on day 35 of pregnancy (Cow 35, fetus on the left, lactating pregnant at second insemination, fetal wt $=0.1 \mathrm{~g}$, placental $w t=6.6 \mathrm{~g}$; Cow 24, fetus on the right, not lactating and pregnant at first insemination, fetal $w t=1.2 \mathrm{~g}$, placental $w t=17.8 \mathrm{~g}$ ). First insemination occurred at 61 days postpartum. Cow 24 was CIDR-treated because she did not have a corpus luteum at the time of first GnRH of the synchronization program. Cow 35 was not pregnant at first Al but she was not observed in estrus between day 80 and 85 so she was retreated with PGF on day 93 and reinseminated.

Two (one lactating and one nonlactating) of the 42 cows did experience embryonic loss as evidenced by a positive blood PAG test but fetal and placental tissue in the horn that appeared necrotic. Although fertility for the two treatments was the same, we did note the expected difference in interval to first ovulation with lactating cows ovulating later postpartum than nonlactating cows (Table 1). Although the interval to first ovulation was lengthened by lactation, there was no evidence for an effect of lactation on the weight of the CL (Table 2), blood progesterone concentrations (Fig. 3), or blood estradiol concentrations before insemination (Fig. 4B). Despite the lack of an observed effect of lactation, we did find that cows that were pregnant after first Al had greater blood estradiol concentrations preceding the first Al (Fig. 4A). This difference in estradiol implied greater functionality of the dominant follicle at the end of the synchronization program; an aspect previously related to fertility within timed Al programs (Perry et al. 2005). Progesterone after breeding was less during the midluteal phase in cows that did not become pregnant after the first Al (Fig. 3). Lesser progesterone in cows that failed to become pregnant after timed $\mathrm{Al}$ has been reported by other investigators as well (Wiltbank et al. 2010) and this may be related to the functionality of the dominant follicle that we mentioned previously in this paragraph (lesser estradiol indicative of a less mature follicle during timed Al; Fig. 4A).

Our inability to detect progesterone and estradiol differences for lactating and nonlactating cows argues against the widely held theory that lactation causes a depression in blood steroid concentrations. Sangsritavong et al. (2002) found that lactating cows had greater metabolic clearance rate of progesterone than nonlactating cows. This difference was explained by greater feed intake in lactating cows. Sartori et al. (2004) showed that nulliparous heifers had greater steroid concentrations but smaller $\mathrm{CL}$ than lactating cows. Their conclusion was that poor reproduction in lactating cows was caused by lesser circulating steroid concentrations. The contrary results that we observed in terms of lactation effects on progesterone (Fig. 3) and estradiol (Fig. 4B) could be explained by the fact that the cows used in this trial were first parity and lower producing relative to multiparous cows. A similar study should be completed with multiparous cattle with greater milk production. The nonlactating cows also had greater BCS relative to the lactating cows and perhaps greater capacity to sequester steroids into body fat (thus affecting steroid clearance).

Plasma NEFA underwent a sustained period of elevated concentrations in lactating cows that did not achieve basal levels until $\sim 40$ days postpartum (Fig. 2A). In the nonlactating cow, NEFA concentrations were less but nonetheless elevated for $\sim 15-20$ days postpartum. Serum NEFA concentrations are correlated with follicular fluid NEFA concentrations (Leroy et al. 2005) and the elevated NEFA concentrations found in postpartum lactating dairy cows can negatively impact oocyte growth and quality (Leroy et al. 2008a). Nonetheless, we did not observe different NEFA profiles in cows that conceived or failed to conceive at first postpartum insemination. We did observe, however, an effect of first insemination status on plasma glucose concentrations. Regardless of whether cows were lactating or nonlactating, those that failed to conceive at first insemination had lesser plasma glucose during the first 30-40 days postpartum (Fig. 2B). After this time ( $>40$ days postpartum), plasma glucose was largely the same for cows within the same treatment that conceived or failed to conceive at first insemination.

As a group, cows that failed to conceive at first insemination compared with those that conceived had lesser blood glucose concentrations (Fig. 2B) and lesser milk production (Fig. 1B). One possibility is that glucose availability was limiting the production of milk; a concept that was demonstrated when late lactation cows were treated with phlorizin to depress blood glucose concentrations (Bradford \& Allen 2005, 2007). Perhaps depressed glucose availability not only affected the capacity of the cows to produce milk (presumably through availability of glucose for lactose synthesis) but 
also in some manner had carry-over effects on their capacity to become pregnant after first insemination. This would most likely occur through the metabolic imprinting of reproductive tissues. The observation that greater milk production is associated with improved reproductive status has been made previously (Staples et al. 1990). The concept of metabolic imprinting of reproductive tissues has been presented as well (Britt 1992). The 'Britt hypothesis' states that early postpartum metabolism can exert carryover effects on the developing oocyte because the oocyte requires $60-80$ days to fully develop within the preovulatory follicle. The oocyte that ovulates around the time of first insemination develops during the early postpartum period under adverse metabolic conditions. We would extend the Britt hypothesis to include the uterus and oviduct because these tissues are repaired through uterine involution that occurs primarily during the first 30 days after calving (Leslie 1983).

The possibility that glucose is a mediator of postpartum reproduction because it acts as a limiting substrate for both milk production and reproduction may be a new idea supported by these experimental findings. The lactating mammary gland is the primary glucose 'sink' in postpartum cows (Bell \& Bauman 1997). Other tissues and cells function in the metabolic environment created by lactation. If the cow is deficient in terms of her blood glucose concentrations then she compromises her lactation. This state of inadequate blood glucose during lactation theoretically compromises the function of other tissues that depend on glucose. For example, glucose is an essential molecule for developing oocytes (Leroy et al. 2008b, SuttonMcDowall et al. 2010), for follicular granulosa and theca cells (Weber \& La Barbera 1988), for the CL (Chase et al. 1992), and for the embryo (Sinclair et al. 2003) and fetus (Battaglia \& Meschia 1978). Low blood glucose could potentially compromise a variety of essential processes in these cells and tissues.

Plasma GH concentrations were elevated in lactating cows (Fig. 2C) presumably because the somatotropic axis remained uncoupled. The uncoupling of the somatotropic axis at calving leads to a decrease in circulating concentrations of IGF1 that exists for at least 60 days postpartum (Fig. 2D). In the lactating cow, glucose is used for the production of lactose and also energy within the mammary gland. The demand for glucose during lactation leads to lesser glucose and lesser insulin concentrations during lactation (Fig. 2E). The lesser insulin theoretically prevents (or slows) the recoupling of the somatotropic axis through its effects on GH receptor 1A (GHR1A; Butler et al. 2003, Lucy 2008). When cows were not milked, the somatotropic axis recoupled within 10 days after calving (evidence by a plateau in plasma IGF1 within 10 days postpartum; Fig. 2D). In the absence of lactation, therefore, plasma IGF1 concentrations normalize rapidly in dairy cattle.
This rapid recoupling in nonlactating cows could perhaps be explained by the rapid normalization of insulin in postpartum cows that are not milked (Fig. 2E).

With respect to pregnancy status, plasma IGF1 was similar to plasma glucose because plasma IGF1 concentrations in cows that failed to conceive at first insemination were depressed, particularly during the first 30-40 days postpartum. As with glucose, the underlying physiology that dictates the relationship between IGF1 and reproductive function is incompletely understood. There are IGF receptors in the uterus and ovary and IGF1 is generally correlated with improved uterine/ovarian health through its actions as a growth factor in the reproductive tract (Velazquez et al. 2008). IGF1 has been shown to promote follicular growth and differentiation (Lucy 2000, Gong 2002, Leroy et al. 2008b). Additionally, low blood IGF1 concentrations are associated with a delay in the resumption of postpartum ovarian activity (Beam \& Butler 1999), an observation that was made for lactating cows in this trial.

The second major finding from this work was that the development of the fetus was faster (greater fetal weight at a given day of gestation) and there was more fetal fluid in cows that conceived after first insemination when compared with cows that conceived after second or third insemination (Table 3). Differences in fetal development were apparently manifested as early as the third week after insemination as evidenced by greater PAG concentrations during the third and fourth weeks in cows that conceived after the first insemination (Fig. 5). We did observe different metabolic profiles for the respective classifications (pregnant or not pregnant to first insemination) but the observed differences only existed during the first 30 days postpartum and did not exist at the time of first insemination or immediately preceding slaughter. The observation made here imply that the early postpartum period (first 30 days after calving) imprints the reproductive tract to affect the likelihood of pregnancy at first insemination. The existing literature, of course, would support this concept in as much as numerous studies have reported risk factors for pregnancy at first insemination are manifested early postpartum (Dubuc et al. 2011). What is new here is that cows that become pregnant at a later insemination have a pregnancy that develops more slowly. Alleviating the origins of this compromised reproductive state could theoretically improve first insemination conception rate in dairy cows and perhaps improve pregnancy development in cows that fail to conceive at first insemination.

We measured PAG but only in cows that were known to be pregnant. The concentrations of PAG in the plasma were not affected by lactation but were affected by status (whether or not the pregnancy was derived from first insemination or second/third insemination). Cows that conceived at first $\mathrm{Al}$ had greater PAG than cows that conceived at second or third Al (Fig. 5) but this difference 
only existed before day 35 of pregnancy. In addition to the results presented in Fig. 5 we found that larger fetuses produced greater amounts of PAG than the smaller fetuses (data not shown). When we examined the actual PAG concentrations in two day 35 fetuses with extremely different size we found numeric difference in PAG concentrations (Fig. 6). The PAG results (Fig. 5) supported the notion that cows that become pregnant at first insemination have larger pregnancies (Table 3). It may be possible to use plasma PAG concentrations to assess embryonic development; particularly during the first 35 days of pregnancy.

One limitation of this study was that the nonlactating cows had greater BW and BCS than the lactating cows. Cows were housed together in the same pen and fed the same diet. Keeping nonlactating cows in a separate pen and feeding a separate lower energy diet would have lowered BW and BCS but would have confounded pen and diet with treatment (lactating vs nonlactating). In this study, we opted to not to confound treatment and accepted the potential consequences that greater BW and BCS in nonlactating cows may have had on the results that we observed. There is an optimum BCS for reproduction in cattle that is centered at a BCS of 3.5 (Roche et al. 2009). Cows above and below this optimum have inferior reproduction. The nonlactating cows in this study had a BCS of 3.8 on week 12 (Fig. 1A). A caveat of this work, therefore, was the possibility that some of the effects that we observed were a consequence of the high BCS in nonlactating cows and not a consequence of the physiological state of lactation.

In summary, lactation did not affect the establishment of pregnancy but instead negatively affected the weight of the placenta and fetus between day 28 and 42 in primiparous Holstein cows. The mechanisms through which this occurred may involve large differences in hormone $(\mathrm{GH}, \mathrm{IGF} 1$, and insulin) and metabolite (glucose and NEFA) concentrations that existed between lactating and nonlactating cattle. Although lactation affected the interval to first ovulation, we did not observe an effect of lactation on plasma progesterone during three postpartum estrous cycles or an effect of lactation on plasma estradiol before insemination. One surprising result was that cows that were pregnant after the first insemination had larger conceptuses than cows that were pregnant after a second or third insemination. There was an association between pregnancy at first insemination and greater plasma glucose and IGF1 concentrations during the first 30 days postpartum. The implication is that hormonal and metabolic imprinting of the reproductive tract occurs during the early postpartum period. This imprinting can affect the likelihood of pregnancy at first insemination and fetal development for cows that become pregnant after a second or third insemination. Whether or not slower fetal development leads to embryonic loss is an important question that will need to be addressed in future studies.

\section{Materials and Methods}

\section{Animals and sample collection}

The project was approved by the University of MissouriColumbia Animal Care and Use Committee. Cows were housed at the University of Missouri-Columbia Foremost Dairy Farm. Pregnant Bos taurus Holstein heifers $(n=43)$ were randomly assigned to one to two treatment groups: lactating $(n=23)$ and not lactating (nonlactating; $n=20)$. After calving, the lactating group was milked twice daily. The nonlactating group was not milked after calving (i.e. dried off immediately, never milked). Both treatment groups were housed together in a two-row freestall barn. The freestalls were sand bedded and there was a solid concrete floor. A diet consisting of corn silage, alfalfa haylage, grass hay, concentrates, and minerals was provided with equal access via bunk feeding for both treatment groups.

Blood samples were collected from cows thrice weekly following parturition (Monday, Wednesday, and Friday mornings, $\sim 2 \mathrm{~h}$ after feeding) and continued until cows were slaughtered for tissue collection. Blood was collected by venipuncture of the median caudal vein or artery into tubes containing $100 \mu \mathrm{l}$ of a $15 \%$ solution of EDTA $\left(K_{3}\right)$ (Tyco Healthcare Group, Mansfield, MA, USA). Plasma was collected by centrifugation of whole blood (1500 $\mathrm{g}$ for $10 \mathrm{~min}$ ) and was stored at $-20{ }^{\circ} \mathrm{C}$ in polypropylene tubes until analyzed for hormone and metabolite concentrations. Cows were weighed and scored for body condition on Monday mornings. BCS ( $1=$ thin to $5=$ obese) was the average score between two trained individuals that used a common scorecard.

Cows were synchronized with the a 'Presynch-Ovsynch' protocol $\left(\mathrm{PGF}_{2 \alpha}(5 \mathrm{ml}\right.$ Lutalyse i.m., $25 \mathrm{mg}$ dinoprost tromethamine; Pfizer Animal Health, New York, NY, USA), wait 14 days, $\mathrm{PGF}_{2 \alpha}$, wait 12 days, GnRH (2 ml Factrel i.m., $100 \mu \mathrm{g}$ gonadorelin hydrochloride; Pfizer Animal Health), wait 7 days, $\mathrm{PGF}_{2 \alpha}$, wait $56 \mathrm{~h}, \mathrm{GnRH}$, wait $16 \mathrm{~h}, \mathrm{Al}$ ) for first $\mathrm{Al}$ between 56 and 62 days postpartum. Ovarian morphology $(\mathrm{CL}$ and follicles $\geq 5 \mathrm{~mm}$ ) was recorded weekly by using transrectal ultrasonography (Aloka 500-SSD equipped with $7.5 \mathrm{MHz}$ transducer, Aloka, Tokyo, Japan) on Monday mornings. Cows that did not have a CL at the time of the first administration of GnRH were treated intravaginally with progesterone (CIDR device, Pfizer Animal Health) for 7 days (removed at the time of $\mathrm{PGF}_{2 \alpha}$ injection; three lactating and two nonlactating cows were treated with CIDR). All cows were inseminated from a single ejaculate of a high fertility sire (Regancrest-RB Miles, 7HO7037; Select Sires, Plain City, OH, USA). Cows that did not conceive at first service were subsequently reinseminated $12 \mathrm{~h}$ after an observed return to estrus by using semen from the same sire and ejaculate used for first Al. Nonpregnant cows that were not observed in estrus were resynchronized by using an Ovsynch program for timed $\mathrm{Al}$ (GnRH injection, wait 7 days; $\mathrm{PGF}_{2 \alpha}$ injection, wait $56 \mathrm{~h}$; and $\mathrm{GnRH}$ injection, wait $16 \mathrm{~h}, \mathrm{Al}$ ).

Cows were diagnosed as pregnant by using transrectal ultrasonography and by using a rapid ELISA for PAGs (Green et al. 2009). Pregnant cows were slaughtered at 1 of 3 days of pregnancy (28 days (lactating, $n=6$; nonlactating, $n=6 ; 105$ \pm 28 days postpartum), 35 days (lactating, $n=8$; nonlactating, 
$n=6 ; 108 \pm 29$ days postpartum), or 42 days (lactating, $n=8$; nonlactating, $n=6 ; 114 \pm 13$ days postpartum)). Three cows were not included in the analyses because they either did not have a viable pregnancy (dead embryo found) at the time of slaughter (lactating, $n=1$; nonlactating, $n=1$ ) or failed to become pregnant (nonlactating, $n=1$ ). The slaughter was done immediately after the morning milking. Cows were stunned by using a pneumatic captive bolt and then killed by exsanguination. The tract was collected and the weights of the gravid ovary, gravid $\mathrm{CL}$, nongravid ovary, nongravid $\mathrm{CL}$ (if present), fetus, and placenta were measured. The volume of placental fluid and the crown-rump length of the fetus were also recorded.

\section{Plasma hormone assays}

Validated RIAs were used to determine the plasma concentrations of GH (Gorewit 1981), insulin (Kolath et al. 2006), and IGF1 (Rhoads et al. 2008) in the thrice weekly samples from calving up until the day of first $\mathrm{Al}$ ( $\sim 60$ days postpartum). Two RIAs for GH were completed with an intraassay CV of $8.5 \%$ and an interassay $\mathrm{CV}$ of $5.9 \%$. Four RIAs for insulin were completed with an intraassay CV of $7.2 \%$ and an interassay CV of $11.2 \%$. Two RIAs for IGF1 were completed with an intraassay CV of $6.9 \%$ and an interassay CV of $3.8 \%$.

Plasma progesterone and estradiol concentrations were analyzed by validated RIA (Kirby et al. 1997). The plasma progesterone concentrations were measured in the thrice weekly samples from calving up until 28 days after first Al. Ten progesterone RIAs were completed with an interassay CV of $6.4 \%$ and the intraassay CV of $8.6 \%$. Plasma estradiol concentrations were measured at 0 and 2 days relative to the final $\mathrm{PGF}_{2 \alpha}$ injection of the synchronization program (i.e. -3 and -1 days before first timed Al). All estradiol determinations were done within a single assay with an intraassay CV of $9.4 \%$.

\section{PAG assay}

Plasma PAG concentrations were measured in plasma samples of pregnant cows from day 15 until day of slaughter (day 28, 35, or 42). The antibodies and procedures for the ELISA were described by Green et al. (2005). The intraassay CV of was $7.0 \%$.

\section{Plasma metabolite assays}

Plasma glucose concentrations were measured by using a commercially available colorimetric assay kit (Pointe Scientific, Inc., Canton, MI, USA) and by following the manufacturer's protocol. Plasma NEFA concentrations were measured by using the Wako NEFA-HR(2) kit (Wako Diagnostics, Richmond, VA, USA). The glucose and NEFA concentrations of the unknown samples run in duplicate were estimated from standard curves within the respective assays.

\section{Statistical analyses}

Cows were assigned to treatment at calving (lactating or nonlactating) and were subsequently assigned to first insemination pregnancy 'status' based on whether they conceived or failed to conceive at first insemination (pregnant or not pregnant to first insemination; coded as 1 or 0 respectively for 'status' in the statistical model). Cows were sampled on repeated postpartum day for plasma hormone and metabolites (GH, IGF1, insulin, NEFA, and glucose). The statistical model used for these data include the effects of treatment, status, treatment by status, day, treatment by day, status by day, and treatment by status by day. The mixed models procedure (PROC MIXED) of SAS (SAS Inst., Cary, NC, USA) was used with day defined as the repeated variable and cow nested within treatment and status defined as a random effect.

Plasma progesterone concentrations were used to determine the interval to first ovulation (defined as the sample day before the first sustained increase plasma progesterone above $0.5 \mathrm{ng} / \mathrm{ml}$ ). The interval to ovulation (day) was analyzed by using PROC GLM with a model that included treatment, status, and treatment by status. Plasma progesterone concentrations were analyzed by using repeated measures to determine effects of treatment and status during three postpartum periods. A cow was included in this analysis if she responded to an injection of $\mathrm{PGF}_{2 \alpha}$ by having luteolysis and ovulation (indicated by a rise in progesterone within 1 week after $\mathrm{PGF}_{2 \alpha}$ ). Anovular cows were not included in these series of analyses. The first luteal phase (luteal phase 1) began $48 \mathrm{~h}$ after the first injection of $\mathrm{PGF}_{2 \alpha}$ within the synchronization program (day 21-27 postpartum) and ended 14 days later when the second injection of $\mathrm{PGF}_{2 \alpha}$ was administered (day 35-41 postpartum). The second phase (luteal phase 2) began $48 \mathrm{~h}$ after the second injection of $\mathrm{PGF}_{2 \alpha}$ and ended 19 days later when the third injection of $\mathrm{PGF}_{2 \alpha}$ was administered (day 50-64 postpartum). The third and final phase (luteal phase 3 ) included the period before luteolysis and began 2 days before the third and final injection of $\mathrm{PGF}_{2 \alpha}$ and ended 28 days later. The progesterone data were analyzed for each phase by using PROC MIXED and a model that was identical to that used for the hormone and metabolite data described above (i.e. model included treatment, status, and day as well as interactions with cow nested within treatment and status defined as random and day defined as repeated). Plasma estradiol was only analyzed at two times ( 0 and 2 days after the third and final $\mathrm{PGF}_{2 \alpha}$; immediately preceding timed $\mathrm{Al}$ ) and a model identical to that used for progesterone was employed.

The concentrations of PAG after Al were only assessed in samples collected from cows that were pregnant (i.e. the sample analyzed may or may not have been from a cow following first insemination; second or third insemination samples were used if the cow became pregnant after second or third insemination respectively). The PAG data were analyzed by using PROC MIXED and a model that included treatment, status, and day as well as interactions. Cow nested within treatment and status was defined as random and day was defined as repeated.

Data collected at slaughter (size and weight of the embryo, placental weight, CL weight, etc.) were analyzed by using PROC GLM. The statistical model included the effects of treatment, status, day, and interactions. Data are reported as least square means \pm s.E.M. A result was viewed as statistically significant if $P<0.05$. A tendency for statistical significance was $0.05<P<0.10$. Comparisons with $P>0.10$ were reported as not significant (NS). 


\section{Declaration of interest}

The authors declare that there is no conflict of interest that could be perceived as prejudicing the impartiality of the research reported.

\section{Funding}

This research was supported by the University of Missouri Experiment Station, the Food for the 21st Century program of the University of Missouri and Pfizer Animal Health (Kalamazoo, MI).

\section{Acknowledgements}

The authors would like to thank members of the Division of Animal Sciences at the University of Missouri including A Perretta, A Brauch, and C Okamura for performing laboratory analysis, J A Green for providing reagents and expertise for the PAG analyses, J Denbigh and E Adkins for the cooperation and services of the Foremost Dairy Farm, and R Disselhorst for collection of tissues at the abattoir.

\section{References}

Battaglia FC \& Meschia G 1978 Principal substrates of fetal metabolism. Physiological Reviews 58 499-527.

Bauman DE \& Currie WB 1980 Partitioning of nutrients during pregnancy and lactation: a review of mechanisms involving homeostasis and homeorhesis. Journal of Dairy Science 63 1514-1529. (doi:10.3168/jds. S0022-0302(80)83111-0)

Beam SW \& Butler WR 1999 Effects of energy balance on follicular development and first ovulation in postpartum dairy cows. Journal of Reproduction and Fertility Supplement 54 411-424.

Bell AW \& Bauman DE 1997 Adaptations of glucose metabolism during pregnancy and lactation. Journal of Mammary Gland Biology and Neoplasia 2 265-278. (doi:10.1023/A:1026336505343)

Berg DK, van Leeuwen J, Beaumont S, Berg M \& Pfeffer PL 2010 Embryo loss in cattle between days 7 and 16 of pregnancy. Theriogenology 73 250-260. (doi:10.1016/j.theriogenology.2009.09.005)

Bradford BJ \& Allen MS 2005 Phlorizin administration increases hepatic gluconeogenic enzyme mRNA abundance but not feed intake in late-lactation dairy cows. Journal of Nutrition 135 2206-2211.

Bradford BJ \& Allen MS 2007 Phlorizin induces lipolysis and alters meal patterns in both early- and late-lactation dairy cows. Journal of Dairy Science 90 1810-1815. (doi:10.3168/jds.2006-631)

Britt JH 1992 Impacts of early postpartum metabolism on follicular development and fertility. Pages 39-43 in the Proceedings of the Annual Convention of the American Association of Bovine Practitioners.

Butler ST, Bork AL, Pelton SH, Radcliff RP, Lucy MC \& Butler WR 2003 Insulin restores hepatic growth hormone $(\mathrm{GH})$ responsiveness during lactation-induced negative energy balance in dairy cattle: effects on expression of insulin-like growth factor-I and $\mathrm{GH}$ receptor 1A. Journal of Endocrinology 176 205-217. (doi:10.1677/joe.0.1760205)

Cetin I \& Alvino G 2009 Intrauterine growth restriction: implications for placental metabolism and transport. A review. Placenta 30 (Suppl A) S77-S82. (doi:10.1016/j.placenta.2008.12.006)

Chase CC Jr, Del Vecchio RP, Smith SB \& Randel RD 1992 In vitro metabolism of glucose by bovine reproductive tissues obtained during the estrous cycle and after calving. Journal of Animal Science $\mathbf{7 0}$ 1496-1508.

De la Sota RL, Lucy MC, Staples CR \& Thatcher WW 1993 Effects of recombinant bovine somatotropin (sometribove) on ovarian function in lactating and nonlactating dairy cows. Journal of Dairy Science $\mathbf{7 6}$ 1002-1013. (doi:10.3168/jds.S0022-0302(93)77428-7)
Diskin MG \& Morris DG 2008 Embryonic and early foetal losses in cattle and other ruminants. Reproduction in Domestic Animals 43 (Suppl 2) 260-267. (doi:10.1111/j.1439-0531.2008.01171.x)

Dubuc J, Duffield TF, Leslie KE, Walton JS \& Leblanc SJ 2011 Effects of postpartum uterine diseases on milk production and culling in dairy cows. Journal of Dairy Science 94 1339-1346. (doi:10.3168/jds.20103758)

Gong JG 2002 Influence of metabolic hormones and nutrition on ovarian follicle development in cattle: practical implications. Domestic Animal Endocrinology 23 229-241. (doi:10.1016/S0739-7240(02)00159-5)

Gorewit RC 1981 Pituitary, thyroid and adrenal responses to clonidine in dairy cattle. Journal of Endocrinological Investigation 4 135-139.

Green JA, Parks TE, Avalle MP, Telegu BP, McLain AL, Peterson AJ, McMillan W, Mathialagan N, Hook RR, Xie S et al. 2005 The establishment of an ELISA for the detection of pregnancy-associated glycoproteins (PAGs) in the serum of pregnant cows and heifers. Theriogenology 63 1481-1503. (doi:10.1016/j.theriogenology.2004.07.011)

Green JC, Volkmann DH, Poock SE, McGrath MF, Ehrhardt M, Moseley AE \& Lucy MC 2009 Technical note: a rapid enzyme-linked immunosorbent assay blood test for pregnancy in dairy and beef cattle. Journal of Dairy Science 92 3819-3824. (doi:10.3168/jds.2009-2120)

King GJ, Atkinson BA \& Robertson HA 1979 Development of the bovine placentome during the second month of gestation. Journal of Reproduction and Fertility 55 173-180. (doi:10.1530/jrf.0.0550173)

King GJ, Atkinson BA \& Robertson HA 1980 Development of the bovine placentome from days 20 to 29 of gestation. Journal of Reproduction and Fertility 59 95-100. (doi:10.1530/jrf.0.0590095)

Kirby CJ, Smith MF, Keisler DH \& Lucy MC 1997 Follicular function in L dairy cows treated with sustained-release bovine somatotropin. Journal of Dairy Science 80 273-285. (doi:10.3168/jds.S0022-0302 (97)75935-6)

Kolath WH, Kerley MS, Golden JW \& Keisler DH 2006 The relationship between mitochondrial function and residual feed intake in Angus steers. Journal of Animal Science 84 861-865. (doi:10.2527/jas.2005-519)

Leroy JL, Vanholder T, Mateusen B, Christophe A, Opsomer G, de Kruif A, Genicot G \& Van Soom A 2005 Non-esterified fatty acids in follicular fluid of dairy cows and their effect on developmental capacity of bovine oocytes in vitro. Reproduction 130 485-495. (doi:10.1530/rep.1.00735)

Leroy JL, Opsomer G, Van Soom A, Goovaerts IG \& Bols PE 2008a Reduced fertility in high-yielding dairy cows: are the oocyte and embryo in danger? Part I. The importance of negative energy balance and altered corpus luteum function to the reduction of oocyte and embryo quality in high-yielding dairy cows Reproduction in Domestic Animals 43 612-622. (doi:10.1111/j.1439-0531.2007.00960.x)

Leroy JL, Van Soom A, Opsomer G, Goovaerts IG \& Bols PE $2008 \mathrm{~b}$ Reduced fertility in high-yielding dairy cows: are the oocyte and embryo in danger? Part II. Mechanisms linking nutrition and reduced oocyte and embryo quality in high-yielding dairy cows Reproduction in Domestic Animals 43 623-632. (doi:10.1111/j.1439-0531.2007.00961.x)

Leslie KE 1983 The events of normal and abnormal postpartum reproductive endocrinology and uterine involution in dairy cows: a review. Canadian Veterinary Journal 24 67-71.

Lucy MC 2000 Regulation of ovarian follicular growth by somatotropin and insulin-like growth factors in cattle. Journal of Dairy Science 83 1635-1647. (doi:10.3168/jds.S0022-0302(00)75032-6)

Lucy MC 2003 Mechanisms linking nutrition and reproduction in postpartum cows. Reproduction Supplement 61 415-427.

Lucy MC 2008 Functional differences in the growth hormone and insulinlike growth factor axis in cattle and pigs: implications for post-partum nutrition and reproduction. Reproduction in Domestic Animals 43 (Suppl 2) 31-39. (doi:10.1111/j.1439-0531.2008.01140.x)

Perry GA, Smith MF, Lucy MC, Green JA, Parks TE, MacNeil MD, Roberts AJ \& Geary TW 2005 Relationship between follicle size at insemination and pregnancy success. PNAS 102 5268-5273. (doi:10.1073/pnas.0501700102)

Purcell SH \& Moley KH 2009 Glucose transporters in gametes and preimplantation embryos. Trends in Endocrinology and Metabolism 20 483-489. (doi:10.1016/j.tem.2009.06.006)

Rhoads ML, Meyer JP, Lamberson WR, Keisler DH \& Lucy MC 2008 Uterine and hepatic gene expression in relation to days postpartum, estrus, and pregnancy in postpartum dairy cows. Journal of Dairy Science $\mathbf{9 1}$ 140-150. (doi:10.3168/jds.2007-0439) 
Roche JR, Friggens NC, Kay JK, Fisher MW, Stafford KJ \& Berry DP 2009 Invited review: body condition score and its association with dairy cow productivity, health, and welfare. Journal of Dairy Science 92 5769-5801. (doi:10.3168/jds.2009-2431)

Sangsritavong S, Combs DK, Sartori R, Armentano LE \& Wiltbank MC 2002 High feed intake increases liver blood flow and metabolism of progesterone and estradiol- $17 \beta$ in dairy cattle. Journal of Dairy Science 85 2831-2842. (doi:10.3168/jds.S0022-0302(02)74370-1)

Santos JE, Thatcher WW, Chebel RC, Cerri RL \& Galvão KN 2004 The effect of embryonic death rates in cattle on the efficacy of estrus synchronization programs. Animal Reproduction Science 82-83 513-535. (doi:10.1016/j.anireprosci.2004.04.015)

Sartori R, Haughian JM, Shaver RD, Rosa GJ \& Wiltbank MC 2004 Comparison of ovarian function and circulating steroids in estrous cycles of Holstein heifers and lactating cows. Journal of Dairy Science 87 905-920. (doi:10.3168/jds.S0022-0302(04)73235-X)

Sinclair KD, Rooke JA \& McEvoy TG 2003 Regulation of nutrient uptake and metabolism in pre-elongation ruminant embryos. Reproduction Supplement 61 371-385.

Staples CR, Thatcher WW \& Clark JH 1990 Relationship between ovarian activity and energy status during the early postpartum period of high producing dairy cows. Journal of Dairy Science 73 938-947. (doi:10.3168/jds.S0022-0302(90)78750-4)

Sutton-McDowall ML, Gilchrist RB \& Thompson JG 2010 The pivotal role of glucose metabolism in determining oocyte developmental competence. Reproduction 139 685-695. (doi:10.1530/REP-09-0345)

Svennersten-Sjaunja K \& Olsson K 2005 Endocrinology of milk production. Domestic Animal Endocrinology 29 241-258. (doi:10.1016/j.domaniend.2005.03.006)
Thatcher WW, Meyer MD \& Danet-Desnoyers G 1995 Maternal recognition of pregnancy. Journal of Reproduction and Fertility Supplement 49 15-28.

Velazquez MA, Spicer LJ \& Wathes DC 2008 The role of endocrine insulinlike growth factor-I (IGF-I) in female bovine reproduction. Domestic Animal Endocrinology 35 325-342. (doi:10.1016/j.domaniend.2008. 07.002)

Walsh SW, Williams EJ \& Evans AC 2011 A review of the causes of poor fertility in high milk producing dairy cows. Animal Reproduction Science 123 127-138. (doi:10.1016/j.anireprosci.2010.12.001)

Weber SL \& La Barbera AR 1988 Insulin, somatomedin-C, human chorionic gonadotropin, and forskolin enhance glucose oxidation by granulosa cells. Biology of Reproduction 38 812-816. (doi:10.1095/biolreprod 38.4.812)

Wiltbank M, Lopez H, Sartori R, Sangsritavong S \& Gümen A 2006 Changes in reproductive physiology of lactating dairy cows due to elevated steroid metabolism. Theriogenology 65 17-29. (doi:10.1016/ j.theriogenology.2005.10.003)

Wiltbank MC, Sartori R, Vasconcelos JL, Nascimento AB, Souza AH, Cunha AP, Gumen A, Sangsritavong S, Guenther JN, Lopez H et al. 2010 Managing the dominant follicle in high-producing dairy cows. Society for Reproduction and Fertility Supplement 67 231-245.

Received 1 December 2011

First decision 4 January 2012

Accepted 27 February 2012 